\title{
Drug Screening and Drug Safety Evaluation by Patch Clamp Technique
}

\author{
Yan Long and Zhiyuan Li \\ Guangzhou Institutes of Biomedicine and Health, Chinese Academy of Sciences
}

China

\section{Introduction}

Ion channels are transmembrane proteins with great importance for the human physiology and become highly attractive molecular drug targets. Ever since the development of patch clamp technique in the late 1970s, it remains the gold standard approach for functional analysis, providing both real time and mechanistic information. Currently, that nearly 400 potential ion channels are found, indicating large-scale ion channel screening of wanted and unwanted drug effects is required (Venter et al., 2001). Unfortunately, it is limited by the lack of adequate screening approach, because available methods put a tradeoff between high-throughput and high-information content. The advent of automated patch clamp platforms revolutionize ion channel screening and enable investigations from a more functional perspective to a much more higher throughput. Compared with conventional patch clamp technique, the current status of automated patch clamp platforms also has some limitations. This chapter will provide the basic concepts of drug screening and drug safety evaluation by patch clamp technique and it moving from conventional to automated trend for high-throughput screening of ion channels.

\section{Ion channels as drug targets}

Ion channels are membrane proteins which form pores allowing ions to pass through impermeable cell membranes mediating and regulating crucial electrical functions throughout the body. Some channels are sensitive to membrane potential alteration and such channels are termed voltage-gated channels. Others have ligand binding sites to which a ligand can bind and change membrane permeability. They are so-called ligand-gated channels. It is estimated that there are more than 400 ion channel genes have been identified in the human genome, including about 170 potassium channels, 38 calcium channels, 29 sodium channels, 58 chloride channels, and 15 glutamate receptors. The remaining are genes encoding other channels such as inositol triphosphate $\left(\mathrm{IP}_{3}\right)$ receptors, transient receptor potential (TRP) channels and others (Venter et al., 2001; Fermini, 2008).

In a range of disorders including pain, epilepsy, depression, stroke, bipolar disorder, COPD, arrhythmia, hypertension, autoimmune disorders and diabetes, over 55 different inherited ion channel diseases, known as 'channelopathies' have now been identified, suggesting ion channels are important therapeutic targets (Table 1) (Ashcroft, 2006). Recently, the 
recognized importance of these proteins in physiological and pathological conditions has led to an extremely active search for ion channel targets in the worldwide drug discovery market. Approximately $13.4 \%$ of known drugs have their primary therapeutic action at ion channels, making them the second largest target class after G-protein coupled receptors (GPCRs) (Overington et al., 2006). These include the nicotinic, $\mathrm{GABA}_{\mathrm{A}}(\gamma$-aminobutyric acid A) and NMDA ( $N$-methyl-d-aspartate) ligand-gated channels, the voltage-gated $\mathrm{Na}^{+}, \mathrm{K}^{+}$and $\mathrm{Ca}^{2+}$ channels, and the ryanodine, inositol 1,4,5-trisphosphate $\left(\mathrm{IP}_{3}\right)$ and transient receptor potential $\mathrm{Ca}^{2+}$ channel families (Imming et al., 2006). Worldwide sales of ion channel drugs are estimated to be in excess of $\$ 12$ billion. For instance, ion channel modulators generated

\begin{tabular}{|c|c|c|c|}
\hline Drug & $\begin{array}{l}\text { Commercial } \\
\text { Name }\end{array}$ & $\begin{array}{l}\text { Target } \\
\text { channel }\end{array}$ & Disease Indication \\
\hline Amlodipine & Norvasc & L-Cav & $\begin{array}{l}\text { Angina, hypertension, arrhythmia (Hogg et } \\
\text { al., 2006) }\end{array}$ \\
\hline Felodipine & Plendil & L-Cav & Hypertension (Hogg et al., 2006) \\
\hline Nifedipine & Adalat & L-Cav & Angina, hypertension (Hogg et al., 2006) \\
\hline Verapamil & \begin{tabular}{|l|} 
Calan/ \\
Verelan
\end{tabular} & L-Cav & $\begin{array}{l}\text { Angina, hypertension, arrhythmia (Hogg et } \\
\text { al., 2006) }\end{array}$ \\
\hline Diltiazem & $\begin{array}{l}\text { Cardizem/ } \\
\text { Tiazac }\end{array}$ & L-Cav & $\begin{array}{l}\text { Angina, hypertension, arrhythmia (Hogg et } \\
\text { al., 2006) }\end{array}$ \\
\hline Nimodipine & Nimotop & L-Cav & $\begin{array}{l}\text { Angina, hypertension, arrhythmia (Hogg et } \\
\text { al., 2006) }\end{array}$ \\
\hline Nifedipine & Procardia & L-Cav & $\begin{array}{l}\text { Angina, hypertension, arrhythmia } \\
\text { (Hogg et al., 2006) }\end{array}$ \\
\hline Carbamazepine & Tegretol & Nav & Epilepsy (Chouinard, 2006) \\
\hline Topiramate & Topamax & Nav & Epilepsy (Chouinard, 2006) \\
\hline Lamotrigine & Lamictal & Nav & Epilepsy (Chouinard, 2006) \\
\hline Flecainide & Tambocor & Nav1.5 & Arrhythmia (Hogg et al., 2006) \\
\hline Lidocaine & Lidocaine & Nav & Local anesthesia (Hogg et al., 2006) \\
\hline Gabapentin & Neurontin & 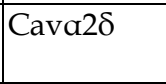 & $\begin{array}{l}\text { Pain (Hamer et al., 2002; Mathew et al., } \\
\text { 2001) }\end{array}$ \\
\hline Glimepiride & Amaryl & KATP & Type-II diabetes (Proks \& Lippiat, 2006) \\
\hline Glibenclimide & Glimepiride & KATP & Diabetes (Proks \& Lippiat, 2006) \\
\hline Nateglimide & Starlix & KATP & Type-II diabetes (Proks \& Lippiat, 2006) \\
\hline Zaleplon & Sonata & $\mathrm{GABA}_{\mathrm{A}}$ & Insomnia (Kozlowski, 1999) \\
\hline Benzodiazepine & Diazepam & GABA & Depression (Kozlowski, 1999) \\
\hline Ziconotide & Prialt & Cav2.2 & Severe chronic pain (Hogg et al., 2006) \\
\hline Lubiprostone & Amitiza & CLC-2 & $\begin{array}{l}\text { Chronic idiopathic constipation } \\
\text { (Kozlowski, 1999) }\end{array}$ \\
\hline Pregabalin & Lyrica & GABA & Neuropathic pain (Kozlowski, 1999) \\
\hline Sotalol & Betapace & hERG & Arrhythmia (Hogg et al., 2006) \\
\hline Amiodarone & Cordorone & hERG & Arrhythmia (Hogg et al., 2006) \\
\hline Phenytion & Dilantin & Nav & Epilepsy (Chouinard, 2006) \\
\hline Flupirtine & Flupirtine & KCNQ2/3 & Epilepsy (Chouinard, 2006) \\
\hline
\end{tabular}

Table 1. Current Ion Channel Drugs 
over $\$ 1.2$ billion sales in 2002. Amlodipine besylate, an antihypertensive of Pfizer inc., generated around $\$ 4$ billion in revenue in 2003. Ambien and Xanax, chloride channel modulators, generated nearly $\$ 2$ billion together in annual sales (Li et al., 2005).

The current ion channel drugs are concluded in table 1, the table indicates that the pharmaceutical industry has successfully developed considerable drugs which targeted at selected calcium, potassium, sodium and chloride channels. Given the number of ion channel genes identified in the human genome project, it appears that there remains a significant pool of unexploited channels for tractable pharmacological target.

\section{The impact of hERG for drug toxicity evaluation}

In addition to being drug targets, as transmembrane proteins, ion channels are easily accessible for small molecules treatment and, in some cases, are also the direct cause of

\begin{tabular}{|c|c|c|c|c|}
\hline \multirow[t]{2}{*}{ Name } & Indicator & Potency & Tissue & Cell \\
\hline & (Channel) & $(\mathrm{IC} 50, \mu \mathrm{M})$ & (Species-Type) & (Type) \\
\hline Astemizole (Salata et al., 1995) & $\begin{array}{c}\mathrm{I}_{\mathrm{kr}} \\
\mathrm{hERG}\end{array}$ & $\begin{array}{c}0.0015 \\
0.069\end{array}$ & GP-VM & $\mathrm{XO}$ \\
\hline $\begin{array}{l}\text { Terfenadine Astemizole (Salata et al., } \\
\text { 1995) }\end{array}$ & $\begin{array}{c}\mathrm{I}_{\mathrm{kr}} \\
\mathrm{hERG} \\
\mathrm{hERG}\end{array}$ & $\begin{array}{c}0.05 \\
0.431 \\
0.35\end{array}$ & Ibid. & $\begin{array}{l}\text { Ibid. } \\
\text { Ibid. }\end{array}$ \\
\hline MK-499 (Spector et al., 1996) & $\begin{array}{c}\text { hERG } \\
\text { WT-hERG }\end{array}$ & $\begin{array}{l}0.123 \\
0.034\end{array}$ & & $\begin{array}{l}\text { Ibid. } \\
\text { Ibid. }\end{array}$ \\
\hline BRL-37872 (Thomas et al., 2001) & $\begin{array}{l}\text { hERG } \\
\text { hERG }\end{array}$ & $\begin{array}{c}0.241 \\
0.0198\end{array}$ & & $\begin{array}{c}\text { Ibid. } \\
\text { HEK293 }\end{array}$ \\
\hline Clofilium (Suessbrich et al., 1997b) & hERG & 0.25 & & $\mathrm{XO}$ \\
\hline LY97241 (Suessbrich et al., 1997b) & hERG & 0.019 & & Ibid. \\
\hline Haloperidol (Suessbrich et al., 1997a) & hERG & 0.024 & & Ibid. \\
\hline $\begin{array}{c}\text { E4031 (Sanguinetti \& Jurkiewicz, } \\
\text { 1990) }\end{array}$ & $\mathrm{I}_{\mathrm{kr}}$ & 0.497 & GP-VM & \\
\hline Quinidine (Woosley, 1996) & $\mathrm{I}_{\mathrm{kr}}$ & 0.2 & F-CM & \\
\hline $\begin{array}{l}\text { Desmethylastemizole (Vorperian et } \\
\text { al., 1996; Zhou et al., 1999) }\end{array}$ & $\begin{array}{c}\mathrm{I}_{\mathrm{kr}} \\
\mathrm{hERG}\end{array}$ & $\begin{array}{c}0.02 \\
0.001 \\
\end{array}$ & Rab-VM & HEK293 \\
\hline Cisapride (Walker et al., 1999) & hERG & 0.0236 & & $\mathrm{CHO}$ \\
\hline Pimozide (Kang et al., 2000) & hERG & 0.018 & & Ibid. \\
\hline Bepridil (Chouabe et al., 1998) & hERG & 0.55 & & COS \\
\hline Droperidol (Drolet et al., 1999) & $\begin{array}{c}\mathrm{I}_{\mathrm{kr}} \\
\mathrm{hERG}\end{array}$ & $\begin{array}{l}0.0276 \\
0.032 \\
\end{array}$ & GP-VM & HEK293 \\
\hline Sertindole (Rampe et al., 1998) & hERG & 0.014 & & L-cells \\
\hline Tedisamil (Zolotoy et al., 2003) & $\mathrm{TdP} *$ & 3 & & \\
\hline Dofetilide (Yang et al., 1995) & $\mathrm{I}_{\mathrm{kr}}$ & 0.012 & & AT-1 \\
\hline Ibutilide (Yang et al., 1995) & $\mathrm{I}_{\mathrm{kr}}$ & 0.02 & & AT-1 \\
\hline $\begin{array}{c}\text { Verapamil (Chouabe et al., 2000; } \\
\text { Waldegger et al., 1999; Zhang et al., } \\
\text { 1999) }\end{array}$ & $\begin{array}{l}\text { hERG } \\
\text { hERG } \\
\text { hERG }\end{array}$ & $\begin{array}{c}0.14 \\
0.83 \\
3.8\end{array}$ & & HEK293 \\
\hline
\end{tabular}

Table 2. Potency of Strong HERG and $\mathrm{I}_{\mathrm{kr}}$ Blockers 
unwanted side-effects. In particular, the discovery of hERG channel and its underling role in prolongation of QT interval brings considerable attention on the drug safety liability issue and leads to the withdrawal or restricted use of several hERG-related drugs since 1997, including antihistamine Seldane, gastric prokinetic drug cisapride, antipsychotic sertindole, and even the antibiotic grepafloxacin (De Bruin et al., 2005; Vitola et al., 1998). Physiologically, hERG channel is closely related to the phase 3 repolarization in the action potential of human ventricular myocytes. The blockade of hERG leads to malfunction in cardiac excitability, clinically defines as either cardiac arrhythmia (torsade de pointes) or long QT syndrome, a cardiac repolarization disorder. In accordance with the requirement of FDA and the European Medicines Agency, before clinical trials, drug testing of known ion channels, especially hERG, are needed in order to rule out possible side effects (Morganroth, 2004).

Compounds that have been validated with strong potency of hERG block are concluded in Table 2

\section{Conventional patch clamp technique}

Sakmann and Neher's patch clamp electrophysiology technique is a highly accurate and sensitive recording method, which revolutionized ion channel research and remains the gold standard approach for functional analysis (Neher \& Sakmann, 1992). Patch clamp technique can be operated in either voltage clamp or current clamp mode. Voltage clamp allows an experimenter to 'clamp' the cell potential at a chosen value. This makes it possible to measure voltage specific activity of ionic channels. The voltage-gated channels are primarily studied in this mode. Current clamp records the membrane potential changes in response to it. This technique is used to study how a cell responds when electrical current enters a cell. This type of recording are performed to study action potential firing by the neuron.

Currently, there are a number of different patch clamp configurations and systems exist. The 'whole-cell' configuration is the most common method for majority cultured cells and tissue preparations. Conventionally, the technique uses a glass microelectrode, sometimes called 'patch pipette', containing an electrolyte resembling the fluid normally found within the cell (tip resistance 1-5 M $\Omega$ ), which is positioned on the cell membrane with the aid of a microscope and micromanipulators, followed by gentle suction through the pipette to start seal formation. Once a high resistance $(>1 G \Omega)$ seal between the rim of recording pipette and cell membrane is formed, further suction is applied to rupture the 'clamped' patch, allowing electrical access to the whole cell. The electrolyte freely dialyses from pipette to cell interior within minutes and the ionic gradients achieves equilibrium between the microelectrode and the cell. Patch clamp amplifier with low noise such as EPC form HEKA Electronik and Axopatch from Axon Instruments is utilized to monitor membrane potential with reference to a bath ground electrode, inject current to clamp the membrane potential to any voltage that we desire and detect current flow. Patch clamp technique can be operated in voltage and current clamp mode, which is, voltage steps or ramps, or current steps are applied to activate channels. Whole cell configuration monitors response of all ion channels within a cell membrane, currents as small as $10 \mathrm{pA}$, representing signals from just a few hundred open channels, can be recorded with sub-millisecond temporal resolution (Penner, 1995).

Perforated patch clamp technique is a variant of whole cell recording method. It differs in which electrical access to the cell interior is obtained via membrane permeabilizing reagents, 
typically nystatin or amphotericin, or with more potent gramicidin and saponin $\beta$-Escin. After these antibiotics added to the internal recording solution, it takes 10-30 minutes to perforate cell. Compared with whole cell approach, it has some advantages, including produces minimal disruption to the intracellular milieu, offers reduced dialysis and generally allows for highly stable recordings, but the access resistance is higher. The main disadvantages are decreased current resolution and increased noise (Penner, 1995).

Cell-attached, inside-out and outside-out patch clamp are called single channel recording technique. They sample channels from a small area $\left(<10 \mu \mathrm{m}^{2}\right)$ of the membrane rather than from the entire cell and study the behavior of ion channels on the section of membrane attached to the pipette. The cell-attached configuration is obtained by simply lowering the pipette onto the cell surface and measures currents arising from the channels which located within the diameter of the tip of recording pipette. A major disadvantage of this configuration is the entirely non-invasive of plasmalemma, making the application of pharmacological modulators to either side of the membrane becomes difficult, for this reason, it is largely restricted to biophysical analysis. By gently withdrawing the electrode from the cell after obtaining gigaohm seal, excising the patch inside the pipette tip, it is possible to form the inside-out recording configuration. With the internal aspect of the cell membrane now is exposed to the bath solution, compound acts on the inner facing channel can be readily achieved. This configuration is useful for studying the effects of alternative intracellular environment on single ion channel function. Outside-out patches are generated by first performing the whole cell recording and then slowly withdrawn the pipette from the cell membrane, a bleb of membrane separates from cell, creating a patch where the external aspect of cell membrane facing the bath solution. This is particularly attractive when studying the effects on single ion channel function of compounds applied to the extracellular solution (Fig 1) (Penner, 1995).

Typically, a conventional patch clamp setup comprises of components as follow (Fig 2) (Kornreich, 2007):

Micropipette puller: used to pull electrode from borosilicate glass capillary tubes. This process usually requires several pulls and may be either horizontal or vertical depending on protocol with user preference. Once pipettes have been pulled, they can be further firepolished by Pipette Beveler.

Air suspension table: uses pressurized cylinders to 'float' the table so as to dampen the microscopic movements and vibrations that may interrupt the recording, and adds to achieve high resistance pipette membrane seals.

Faraday cage: shields the sensitive patch clamp preamplifier from stray electromagnetic fields that may introduce noise into electrophysiological recordings. The microscope and headstage are also most commonly placed inside the Faraday cage. Ideally composed of a copper mesh, the Faraday cage is most effective when connected to a ground source.

Inverted microscope: used to visualize the acutely dissociated cells or cultured cell lines being studied. This is important in order to obtain both good visualization of the cells and unhinder the flexible access of pipettes from the top.

Micromanipulator: used to manipulate the electrode (mounted on the headstage) to contact the acutely dissociated cells or cultured cell lines being studied. Micromanipulators are commercially available in mechanical, hydraulic, motorized and piezoelectric drives. 


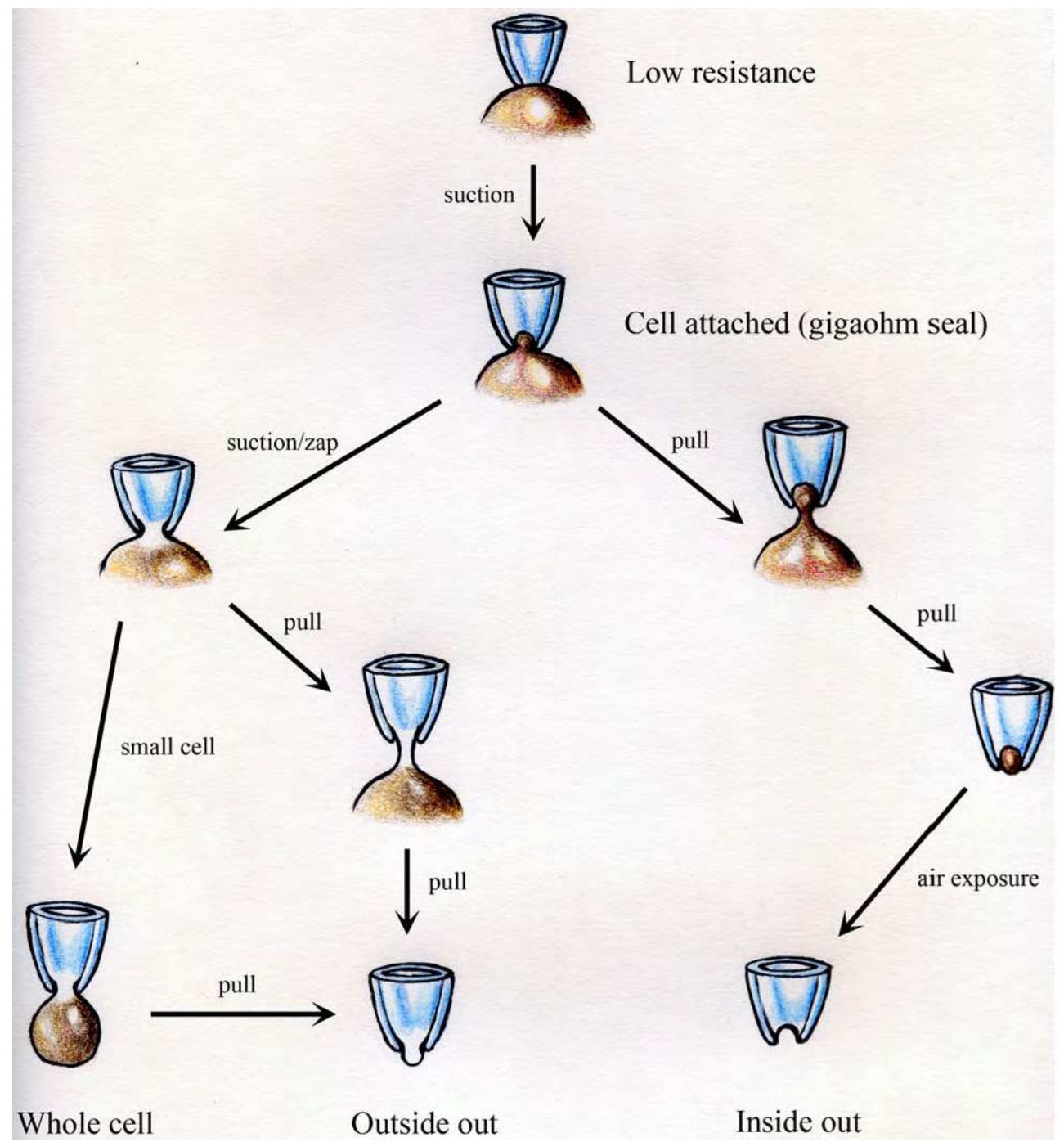

Fig. 1. Formation of different types of patch (Kornreich, 2007)

Amplifier: used to record current or voltage being measured and/or to control membrane voltage (voltage clamp) or current (current clamp) depending on experimental protocol. Additional functions also include filtering of input signal, capacitance compensation, and square wave generation etc. Using suitable software, the patch clamp recordings can be analyzed on a personal computer. For example, Pclamp (Axon), Pulse (Heka) and Jhon Dampaster's WCP (UK) are some of the widely used software.

Digital-analog converter: converts the analog signal recorded by the electrode to digital data, transforms digital output of computer to analog signal at headstage for control of membrane voltage/current, delivers stimulus protocols generated by computer to clamp ion channels. 

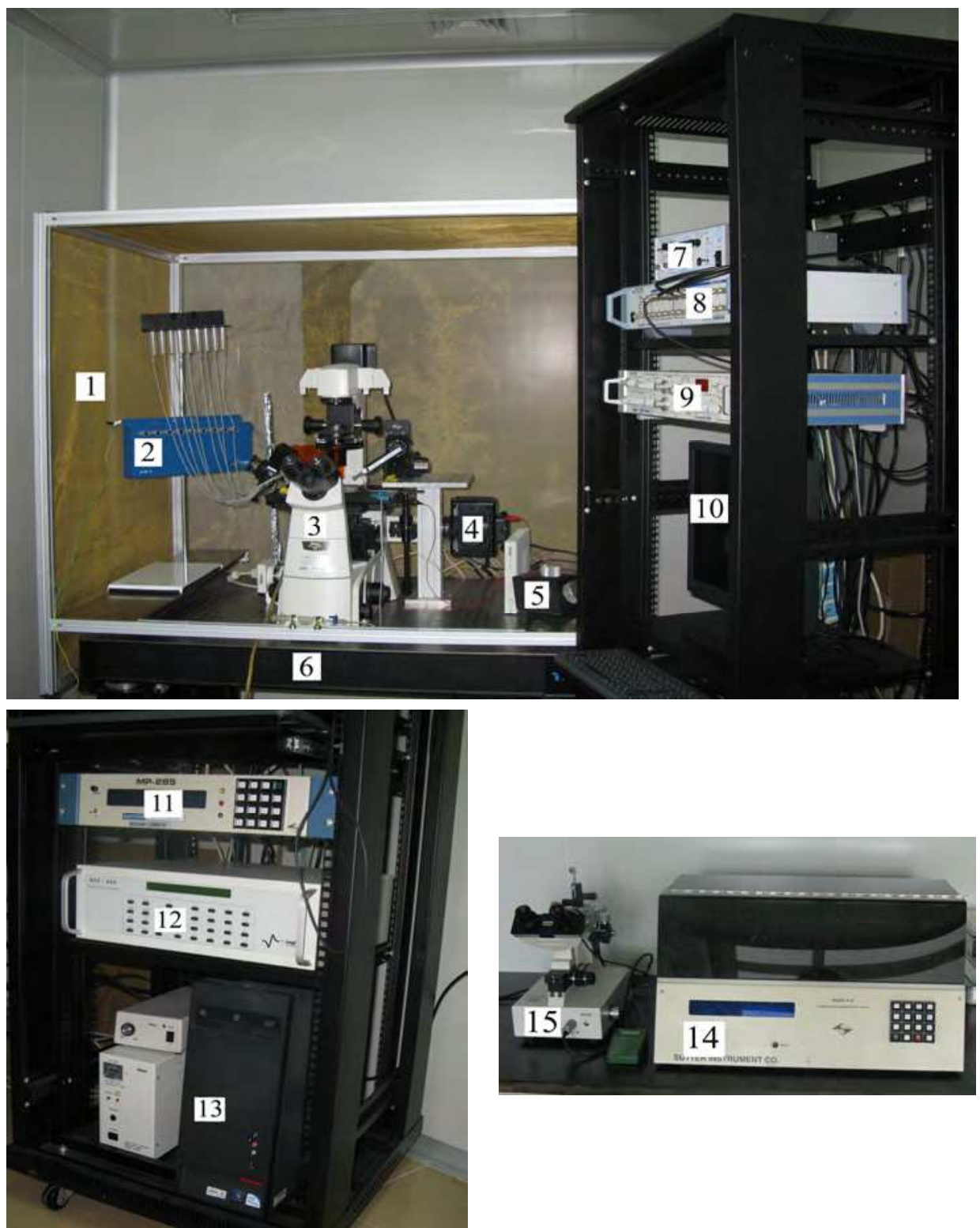

Fig. 2. A conventional patch clamp setup comprising of 1) Faraday cage; 2) Solution perfusion system (EVH-9); 3) Inverted microscope; 4) CCD camera; 5) Motorized micromanipulator controller; 6) Air suspension table; 7) Temperature controller; 8) Digidata; 9) Amplifier (Axopatch 200B); 10) Computer display; 11) Micromanipulator; 12) Rapid solution changer command box (RSC-200); 13) Computer monitor; 14) Micropipette puller; 15) Micropipette Beveler. 
Bath chamber: a small chamber with volume of $500 \mu \mathrm{l}-1 \mathrm{ml}$ used to mount on microscope, during experiments, the cells can be placed in this chamber. A thin glass slide is used to stick the bottom of chamber.

Headstage: it is usually mounted on a micromanipulator, which connects the recording pipette and ground wire and contacts to the amplifier for data acquisition, control of membrane voltage/current, and stimulation release.

Computer: uses suitable software packages to acquire and analyze data. These packages are used to control membrane voltage/current, to process the input/output signals from the amplifier (filtering, capacitance compensation, etc.), to perform stimulus protocols, and to analyze acquired data.

\section{Automated patch clamp technique}

As the state-of-the-art technology for studying ion channels, the patch clamp technique is limited only in the later stages of drug discovery and development, including hits-to-leads, safety testing and basic research, owing to the ultra-low-throughput and time-consuming process. Because of FDA's new recommendations, at the preclinical stage, every drug candidate needs to be evaluated for their potential of hERG channel blockade. Therefore, a high-throughput drug screening approach is required as to accelerate the primary screening of ion channel modulators at the preliminary phase. Using a conventional patch clamp a sophisticated operator can study typically less than 10 cells per day, which is inefficient for large-scale screening for LQTS. Thus, there is a compelling need of high-throughput predictors of ion channel modulation to be developed.

Automated patch clamp setup suitable to high-throughput screening has been marketed. The complicated process of seal formation and current recording has been partially or completely automated. This method utilizes planar chips with small holes, seal forming substrates can either be glass, silicon nitride or plastic. The cells approach to the chips based on computerized feedback controlled application of suction. According to the preprogrammed protocols, the automated patch clamp robots accurately execute operations, in turns of filling the chip with electrolyte solutions, adding cell suspensions, sealing cells onto the holes, breaking through to the whole-cell configuration and performing different voltage-protocols in the absence and presence of drugs while simultaneously recording the ionic currents. The benefit of automated technique is obvious, for instance, the manual handling has been removed from the whole process, machine operation is very straightforward, making it suitable to the nonelectrophysiologists and increasing data reproducibility. Besides, the technology is scalable to array formats, thus parallel recordings of many individual cells can be achieved.

\section{Limitations of automated patch clamping}

Although there are various advantages over the conventional technique, automated technique itself has some limitations. Firstly, it is suitable mainly for stable and highly expressing cell lines. Transiently transfected cell lines are unsuitable for screening. Because cells are captured randomly from cell suspension, which means that the ion channel expression must be homogenous among cells and most cells must be healthy. Primary cultured cells such as cardiac myocytes and neurons have different cell shapes, and do not 
fit the criteria of the platform's random loading system. In addition, the cultured primary cells often contain different cell types and that the suspensions are not 'clean' enough. However, there are some publications reported that the Ionworks and Patchliner have been used for primary cells (Estes et al., 2008). Other issues include some systems can not be used to study of ligand-gated ion channels, temperature control is unavailable, and when screening tens of thousands of compounds, the cost of the tips and chips is considerable high. Currently, most automated patch clamp systems are really limited in their applications and are not particularly useful for academic researches. The main practical application of automated patch clamp is secondary drug screening and safety profiling of hERG ion channel block.

\section{Available automated patch clamp systems}

There are several automated platforms commercially available, the first one appear into market was Ionworks HT and later Ionworks Quattro (Molecular Devices Corporation), succeeded by the Patch Xpress (Molecular Devices Corporation.) and Nanion's Port-a-Patch. Other patch providers include Sophion's QPatch-16 and -48, Flyion's Flyscreen, Nanion's Patchliner platform, Cytocentrics's Cytopatch and Cellectricon's Dynaflow Proll, providing 16 to even 384 parallel recordings on a chip. Some of which including the PatchXpress, Porta-Patch, Patchliner, Flyscreen and the QPatch are the true giga-seal patch clamp recording platforms (Table 3).

The above systems differ in some aspects, for instance, they adopt different solutions according to different materials used for the wells such as glass, silica or polymer, the number of wells on a chip can be various, commonly from 8 to 384, some systems utilize the technology of laminar solution flow in order to exchange different microfluids containing targeted compounds. The quality of the laminar flow is important because when evaluating the effects of different candidates or different concentrations of a candidate on ion channels, the fluids have to be completely exchanged without mixing (Neubert, 2004). Currently, there are two kinds of approaches with cells loading, one is the Flyscreen's 'Flip-the-tip' technology, in this technique the cells are loaded in the specially designed pipette named 'Flip-tips' or 'Chip-tips', and the cells are allowed to reach the tip. In contrast to the conventional method, external solution is filled in the pipette. The other is 'Planar array', which refers to the use of multi-well configurations in either a plate-based or a chip-based format to record multiple cells in parallel. In this technique, cells are loaded abruptly in the well and applying suction below the hole of the plates. Schematic representations of system assemblies (including bath, perfusion, cell trapping, and electrodes) are provided for each in Fig. 3.

\section{8. lonworks}

Flyscreen: patch clamp robot Flyscreen 8500 from Flyion is a fully automated patch clamp system which is now commercially available in academic researches since 2003 (LeppleWienhues et al., 2003). It uses flip-the-tip technology with glass capillaries rather than the planar-array based approach, in this system, cells are patch clamped on the inside rim of the pipette tip, different from conventional patch clamp. The so-called 'flip-tips' or 'chip-tips' are used to perform recordings. When cells travel to the pipette tips by gravity, only slight suction can lead to the formation of a gigaseal. The Flyscreen is also available with temperature control and allows recording at physiological temperature. This instrument is 
designed to be scalable of asynchronously handling 1-6 recording positions and claims to have a throughput of 100-500 data points per day.

IonWorks HT and IonWorks Quattro: the IonWorks HT system from Molecular Devices was the first marketed automated screening system with planar array-based approach in 2003 (Schroeder et al., 2003). It uses a planar, multi-well plate named PatchPlate ${ }^{\mathrm{TM}}$ to replace the patch pipette (Fig. 3a). According to Molecular devices' reports, this disposable 'electrode' contains 384 wells, however, the recording head has only 48 amplifiers, therefore the IonWorks HT is capable of sampling cells sequentially, imposing discontinuity in the recording of currents. In 2006, the upgraded IonWorks Quattro system was launched (Finkel et al., 2006). This technology belongs to the population patch clamp, differs in the IonWorks HT system's recording mode of one cell in one hole in each well, it has 64 cells in 64 holes (in an $8 \times 8$ array) for each well (Fig. $3 b$ ), hence measured ion current from each well would be averaged and eliminates the cell-to-cell differences during recording.

A major drawback of either the HT version or the Quattro version is that they do not support giga-seal recordings, the seal resistance is on the order of $100 \mathrm{M} \Omega$. This low seal resistance induces low data quality, owing to lower signal-to-noise ratio. Furthermore, an antibiotic amphotericin B, rather than suction is used to permeabilize the cell membrane and results in a drastically higher access resistance compared to conventional patch clamping, which in turn leads to poor voltage control over the membrane, possibly altering current amplitude and creates errors in quantification the pharmacology of the ion channels and drugs under investigation. Besides, another drawback of this system is the discontinuous recording during compound administration, which makes it not an ideal platform which suited to recording fast transient currents or ligand-gated currents. However, the Ionworks reports that more than $95 \%$ success rate has proved to be obtained, and it measures about 3000 data points per day, this throughput has known to be the highest and is unmatched by other currently marketed devices, hence making it suitable for primary screening, secondary screening and safety assessment.

PatchXpress 7000A: the second developed planar-array based automated screening system was the PatchXpress from Molecular Devices, it was also the first automated device on the market supporting true giga-seal recording and can analyze both ligand-gated and voltagegated ion channels (Tao et al., 2004; Xu et al., 2003). Their in-house developed software has versatile programming features, which is useful in testing operation and data analysis, and allows for continuous recordings during multiple drug concentrations' applications. This system uses Aviva Bioscience's SealChips, a 16-well disposable that has been reported to patch more than 12 cells (one cell per well) simultaneously for more than 15 min (Fig. 3d). Because of its high giga-seal rates, the longevity of seals comparable to glass pipettes, its versatile software allows the user to program any experimental protocol and its versatility of suitable to all kinds of ion channels. The PatchXpress has been considered as the golden standard in the field for automated electrophysiology. However, its throughput is stated to be 250-300 data points per day, compared with the throughputs of other available systems, is too low for true high-throughput screening.

Port-a-Patch and Patchliner: in 2003, Nanion introduced its first automated patch clamp system, the Port-a-Patch which is the third system marketed to automate voltage clamping. It is currently the world's smallest patch clamp setup with low maintenance setup. This system uses borosilicate glass chips which named NPC-chips as recording substrates. Port- 
a-Patch is a one-cell-at-a-time system. In 2006, Nanion attempted a higher-throughput device, the Patchliner, which supports true giga-seal recordings from up to eight cells simultaneously. It also expands the microfluidic exchange capability of both the internal and the external solutions (Farre et al., 2007). Three NPC-16 chips can be mounted on the chip loading area which means that up to 48 experiments can be preprogrammed and executed, where patch clamp measurements are possible in the whole-cell, cell-attached and perforated-patch recording configurations, and temperature controller in these two platforms supports experiments at physiological temperatures (Fig 3e). The Port-a-Patch has an approximate date throughput of 50 data points per day, whereas the Patchliner is capable of 500 data points per day. The throughput for this device was insufficient to compete successfully on the market and has remained unpopular. Recently, Nanion developed the SyncroPatch 96, which uses 96-well chips and has 96 simultaneous recording heads, with a throughput comparable to that of the IonWorks Quattro.

CytoPatch: the Cytocentrics's CytoPatch was the fourth system launched, this platform also uses planar-based array approach, but its designer has a slight difference from previous systems (Stett et al., 2003). It adopts Cytopatch ${ }^{\mathrm{TM}}$ Chips and Cytopatch ${ }^{\mathrm{TM}}$ Automat as electrode tip, which containing two opening, one for applying negative pressure to suction and to position the cells while simultaneously applying positive pressure to the "electrode tip" to keep it clean, the other for patch clamping and recording (Fig. 3f). These chips can be manufactured in large numbers at low cost and provide the formation of gigaohm seal. Although this device was released in 2003, there was no validation data available till now.

QPatch: the Sophion's QPatch was the fifth automated giga-seal system released (Fig. 3c) in 2004, which can be applied to both voltage- and ligand-gated channels (Mathes, 2006). This workstation can be manipulated and data can be analyzed with in-house developed software in computers. The first marketed system is QPatch 16 which uses QPlates as recording chips. This system provides 16 continuous recordings with 16 simultaneous headstages. To get a further higher throughput, Sophion recently launched the QPatchHT, increased the number of headstages to 48 providing parallel recordings of 48 cells at a time. The stated throughput of the 16-amplifier system is $250-1200$ data points and a significant enhancement of 750-3500 data points per day for the HT-system. Because of the high-quality recordings and the increased throughput, QPatch now has received quite good market acceptance.

Between 2007 and 2009, Fluxion Biosciences employed the so-called lateral patch clamp principle and introduced the IonFlux, a 16× precursor and the upcoming IonFlux HT (Fig. $3 g$ )( Pearson, 2009). IonFlux uses PDMS-based microfluidic chips, according to the company, producing 8,000-10,000 data per day with a 96× consumable. In collaborate with AstraZeneca and The Automation Partnership (TAP), Cellectricon employs their laminarflow solution control to develop a recently announced Dynaflow ${ }^{\circledR H T}$ (Fig. 3h) (Dabrowski, 2009). The system uses 96-well microfluidic chips made from silicone which enable to rapid solution exchange. The system achieved over 7,500 data points per day at first, but with the introduction of a new chip in 2009, the Dynaflow HT system generates 18,000 data points per day. Consistent with the IonFlux HT workstaion and many other high-throughput planar devices, Dynaflow HT has been validated with multiple cell lines including both voltage- and ligand-gated ion channels. 


\begin{tabular}{|c|c|c|c|c|}
\hline Method & Configuration & Format & Advantages & Shortcomings \\
\hline \multicolumn{5}{|c|}{ QPatch (Sophion Bioscience) } \\
\hline $\begin{array}{l}\text { Planar } \\
\text { QPlate with } \\
\text { embedded } \\
\text { recording } \\
\text { and ground } \\
\text { contacts }\end{array}$ & $\begin{array}{l}\text { WC; gigaohm } \\
\text { seals }\end{array}$ & $\begin{array}{l}16 \text { or } 48 \text { wells in } \\
\text { parallel; } 1 \\
\text { cell/hole/well }\end{array}$ & $\begin{array}{l}\text { - Laminar solution } \\
\text { flow } \\
\text { - Ligand addition } \\
\text { during recordings } \\
\text { - Cumulative/multiple } \\
\text { compound additions } \\
\text { - Continuous voltage } \\
\text { clamp and current } \\
\text { vs. time experiment } \\
\text { flow } \\
\text { - Validated for human } \\
\text { ERG } \\
\text { - Electrophysiological } \\
\text { responses similar to } \\
\text { those of conventional } \\
\text { techniques }\end{array}$ & $\begin{array}{l}\text { - Drug } \mathrm{EC}_{50} \\
\text { influenced by } \\
\text { adherence to } \\
\text { plate surfaces } \\
\text { - No intracellular } \\
\text { perfusion } \\
\text { - No } \\
\text { simultaneous } \\
\text { visualization of } \\
\text { channels }\end{array}$ \\
\hline \multicolumn{5}{|c|}{ PatchXpress (Molecular Devices) } \\
\hline $\begin{array}{l}\text { Planar } \\
\text { SealChip } \\
\text { with } \\
\text { electrodes } \\
\text { separate } \\
\text { from chip }\end{array}$ & $\begin{array}{l}\text { WC; gigaohm } \\
\text { seals }\end{array}$ & $\begin{array}{l}16 \text { wells in } \\
\text { parallel; } 1 \\
\text { cell/hole/well }\end{array}$ & $\begin{array}{l}\text { - Continuous voltage } \\
\text { clamp vs. time plots } \\
\text { - Cumulative/multiple } \\
\text { compound additions } \\
\text { - Ligand addition } \\
\text { during recording } \\
\text { - Simultaneous } \\
\text { visualization of all } 16 \\
\text { channels } \\
\text { - Validated for human } \\
\text { ERG } \\
\text { - Electrophysiological } \\
\text { responses similar } \\
\text { to those of } \\
\text { conventional } \\
\text { techniques }\end{array}$ & $\begin{array}{l}\text { - Drug } \mathrm{EC}_{50} \\
\text { influenced by } \\
\text { adherence to } \\
\text { plate surfaces } \\
\text { - No intracellular } \\
\text { perfusion }\end{array}$ \\
\hline \multicolumn{5}{|c|}{ IonWorks HT and Quattro (Molecular Devices) } \\
\hline $\begin{array}{l}\text { Planar 384- } \\
\text { well } \\
\text { PatchPlate }\end{array}$ & $\begin{array}{l}\text { Perforated } \\
\text { WC; } 100 \mathrm{M} \Omega \\
(\mathrm{HT}) \text { or } 30-50\end{array}$ & $\begin{array}{l}384 \text { wells; } 48 \\
\text { channels } \\
\text { sequentially; } 1\end{array}$ & $\begin{array}{l}\text { - Highest-throughput } \\
\text { unit } \\
\text { - Allows for collection }\end{array}$ & $\begin{array}{l}\text { - Drug } \mathrm{EC}_{50} \\
\text { influenced by } \\
\text { adherence to }\end{array}$ \\
\hline
\end{tabular}




\begin{tabular}{|c|c|c|c|c|}
\hline \multirow[t]{2}{*}{ Method } & Configuration & Format & Advantages & Shortcomings \\
\hline & $\begin{array}{l}\mathrm{M} \Omega \text { (Quattro) } \\
\text { seals }\end{array}$ & $\begin{array}{l}\text { cell/hole/well } \\
\text { (HT) or } 64 \\
\text { cells/holes/well } \\
\text { (Quattro) }\end{array}$ & $\begin{array}{l}\text { of } 384 \text { data points: } \\
\sim 60 \% \text { success rate for } \\
\text { IonWorks HT and } \\
>95 \% \text { for IonWorks } \\
\text { Quattro }\end{array}$ & $\begin{array}{l}\text { plate surfaces } \\
\text { - No high- } \\
\text { resistance } \\
\text { membrane seal } \\
\text { - No } \\
\text { simultaneous } \\
\text { ligand addition } \\
\text { and recording } \\
\text { - No intracellular } \\
\text { perfusion } \\
\text { - No voltage } \\
\text { clamp between } \\
\text { reads }\end{array}$ \\
\hline \multicolumn{5}{|c|}{ Patchliner (Nanion Technologies) } \\
\hline $\begin{array}{l}\text { Planar } \\
\text { NPC-16 } \\
\text { chip }\end{array}$ & $\begin{array}{l}\text { WC; gigaohm } \\
\text { seals }\end{array}$ & $\begin{array}{l}2,4 \text {, or } 8 \text { wells } \\
\text { in parallel; } 1 \\
\text { cell/hole/well } \\
\text { (Port-a-Patch) }\end{array}$ & $\begin{array}{l}\text { - Borosilicate chip } \\
\text { surface } \\
\text { - Primary cell use } \\
\text { possible (single-well } \\
\text { version) } \\
\text { - Internal and external } \\
\text { perfusion } \\
\text { - Continuous voltage } \\
\text { vs. time plots } \\
\text { - Ligand addition } \\
\text { during recordings } \\
\text { - Cumulative/multiple } \\
\text { compound additions }\end{array}$ & $\begin{array}{l}\text { - System } \\
\text { performance } \\
\text { information } \\
\text { limited }\end{array}$ \\
\hline \multicolumn{5}{|c|}{ SyncroPatch96 (Nanion Technologies) } \\
\hline Planar chip & $\begin{array}{l}\text { WC; gigaohm } \\
\text { seals }\end{array}$ & $\begin{array}{l}\text { 96-well plates; } \\
16 \text { channels } \\
\text { sequentially; } 1 \\
\text { cell/hole/well }\end{array}$ & $\begin{array}{l}\text { - } \text { Borosilicate chip } \\
\text { surface } \\
\text { - Ligand addition } \\
\text { during recordings } \\
\text { - Internal and external } \\
\text { perfusion } \\
\text { - Continuous voltage } \\
\text { vs. time plots } \\
\text { - Cumulative/multiple } \\
\text { compound additions }\end{array}$ & $\begin{array}{l}\text { - Requires a } \\
\text { proprietary add- } \\
\text { in to solutions to } \\
\text { achieve higher } \\
\text { seal rate } \\
\text { - Though meant } \\
\text { for } 96 x \text {, does not } \\
\text { contain } 96 \\
\text { amplifiers }\end{array}$ \\
\hline
\end{tabular}




\begin{tabular}{|c|c|c|c|c|}
\hline Method & Configuration & Format & Advantages & Shortcomings \\
\hline \multicolumn{5}{|c|}{ CytoPatch (Cytocentrics) } \\
\hline $\begin{array}{l}\text { Planar, } \\
\text { electrode } \\
\text { tip shape } \\
\text { surrounded } \\
\text { by aperture } \\
\text { in } \\
\text { borosilicate } \\
\text { glass } \\
\text { surface }\end{array}$ & WC & 1 cell/hole/well & $\begin{array}{l}\text { - Constant laminar } \\
\text { flow } \\
\text { - Positive pressure on } \\
\text { electrode is } \\
\text { independent of } \\
\text { suction in } \\
\text { surrounding aperture } \\
\text { (mimics manual } \\
\text { patch clamp) }\end{array}$ & $\begin{array}{l}\text { - Not } \\
\text { commercially } \\
\text { available; used } \\
\text { only for in- } \\
\text { house screening }\end{array}$ \\
\hline \multicolumn{5}{|c|}{ IonFlux HT (Fluxion Biosciences) } \\
\hline $\begin{array}{l}\text { Microfluidic } \\
\text { well plate }\end{array}$ & $\begin{array}{l}\text { WC; } \\
\text { megaohm } \\
\text { seals }\end{array}$ & $\begin{array}{l}96-\text { or } 384-w e l l ; \\
16 \text { or } 64(\mathrm{HT}) \\
\text { amplifier arrays; } \\
20 \text { cell ensemble } \\
\text { recordings }\end{array}$ & $\begin{array}{l}\text { - Laminar solution } \\
\text { flow } \\
\text { - Ligand addition } \\
\text { during recordings } \\
\text { - Cumulative/multiple } \\
\text { compound additions } \\
\text { - Continuous voltage } \\
\text { vs. time plots } \\
\text { - Tested with voltage- } \\
\text { and ligand-gated } \\
\text { channels } \\
\text { - Separate cell and } \\
\text { ligand wells }\end{array}$ & $\begin{array}{l}\text { - Drug } \mathrm{EC}_{50} \\
\text { influenced by } \\
\text { adherence to } \\
\text { polymer plate } \\
\text { surfaces? } \\
\text { - No high- } \\
\text { resistance } \\
\text { membrane seal }\end{array}$ \\
\hline \multicolumn{5}{|c|}{ Dynaflow HT (Cellectricon / The Automation Partnership / Astra Zeneca) } \\
\hline $\begin{array}{l}\text { Microfluidic } \\
\text { well plate }\end{array}$ & $\begin{array}{l}\text { WC; } \\
\text { megaohm } \\
\text { seals }\end{array}$ & $\begin{array}{l}96 \\
\text { channels/plate }\end{array}$ & $\begin{array}{l}\text { - Ligand addition } \\
\text { during recordings } \\
\text { - Cumulative/multiple } \\
\text { compound additions } \\
\text { - Silica microfluidic } \\
\text { chip minimizes } \\
\text { compound adherence } \\
\text { and consequent EC50 } \\
\text { shifting } \\
\text { - Validated for human } \\
\text { ERG and GABA }\end{array}$ & $\begin{array}{l}\text { - No high- } \\
\text { resistance } \\
\text { membrane seal }\end{array}$ \\
\hline
\end{tabular}

Table 3. Automated planar-array based platforms (Carmelle et al., 2011; Dunlop et al., 2008). 


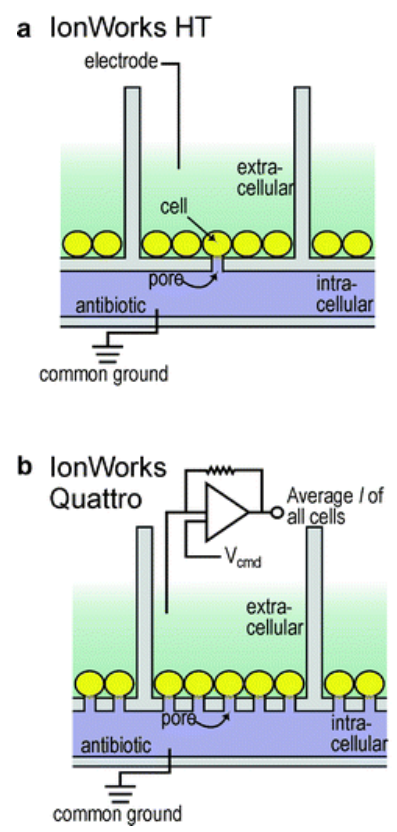

c QPatch

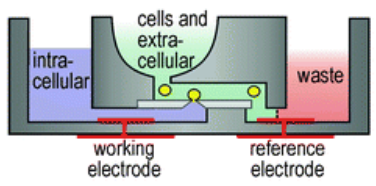

d PatchXpress

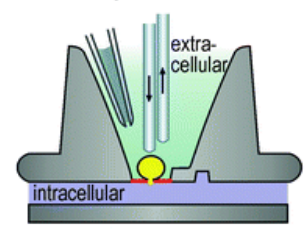

e NPC-16

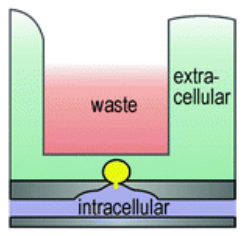

f CytoPatch

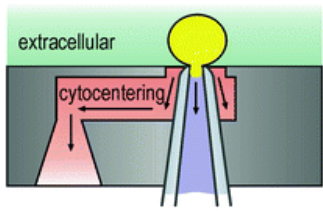

g lonFlux HT

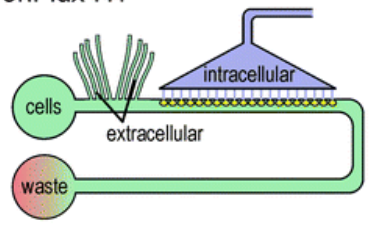

h Dynaflow HT

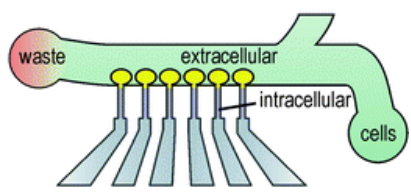

Fig. 3. Chamber configurations for automated and planar patch clamp technologies. (a) PatchPlate used in IonWorks HT. (b) PatchPlate population chip used in IonWorks Quattro. (c) QPlate used in QPatch. (d)SealChip used in PatchXpress. (e) NPC-16 chip used in Patchliner NPC-16. (f) CytoPatch chip used in CytoPatch. (g) Microfluidic bath used in the IonFlux HT system. (h) Microfluidic bath used in the Dynaflow HT syste (Carmelle, 2011)

\section{Future directions for new drug discovery}

The development of new drugs targeted to ion channels is a fast-growing market. Along with the costs of automated screening drop over time and the modification of patch clamp devices gradually live up to expectations, the manufacturers of patch clamp equipment have already acquired considerable number of orders during the past few years from pharmaceutical companies and numerous screening service providers. Recently, patch clamp combined with fluorescent techniques are developed, this technology has achieved in a small number of channels, allowing to simultaneously recording of fluorescence and currents, hence providing correlation between changes in channel structure and alterations in channel function (Zheng, 2006). These progresses open a new visual field in the upcoming era of ion channels studying as well as drug discovery.

\section{References}

Ashcroft, F.M. (2006). From molecule to malady. Nature 440, 440-447

Carmelle, V., Remillard \& Jason, X.J. Yuan. (2011) Conventional patch clamp techniques and high-throughput patch clamp recordings on a chip for measuring ion channel activity. Textbook of pulmonary vascular disease, part 2, 495-510, DOI: 10.1007/978-0387-87429-6_34 
Chouabe, C., Drici, M.D., Romey, G. \& Barhanin, J. (2000). Effects of calcium channel blockers on cloned cardiac K+ channels IKr and IKs. Therapie 55, 195-202

Chouabe, C., Drici, M.D., Romey, G., Barhanin, J. \& Lazdunski, M. (1998). HERG and KvLQT1/IsK, the cardiac $\mathrm{K}^{+}$channels involved in long QT syndromes, are targets for calcium channel blockers. Mol Pharmacol 54, 695-703

Chouinard, G. (2006). The search for new off-label indications for antidepressant, antianxiety, antipsychotic and anticonvulsant drugs. J Psychiatry Neurosci 31, 168176

Dabrowski, M. (2009) Global ion channel initiative. Ion Channel Retreat June 29-July 1 See also the Cellectricon web site

De Bruin, M.L., Pettersson, M., Meyboom, R.H., Hoes, A.W. \& Leufkens, H.G. (2005). AntiHERG activity and the risk of drug-induced arrhythmias and sudden death. Eur Heart J 26, 590-597

Drolet, B., Zhang, S., Deschenes, D., Rail, J., Nadeau, S., Zhou, Z., January, C.T. \& Turgeon, J. (1999). Droperidol lengthens cardiac repolarization due to block of the rapid component of the delayed rectifier potassium current. J Cardiovasc Electrophysiol $10,1597-1604$

Dunlop, J., Bowlby, M., Peri, R., Vasilyev, D. \& Arias, R. (2008). High-throughput electrophysiology: an emerging paradigm for ion-channel screening and physiology. Nat Rev Drug Discov 7, 358-368

Estes, D.J., Memarsadeghi, S., Lundy, S.K., Marti, F., Mikol, D.D., Fox, D.A. \& Mayer, M. (2008). High-throughput profiling of ion channel activity in primary human lymphocytes. Anal Chem 80, 3728-3735

Farre, C., Stoelzle, S., Haarmann, C., George, M., Bruggemann, A. \& Fertig, N. (2007). Automated ion channel screening: patch clamping made easy. Expert Opin Ther Targets 11, 557-565

Finkel, A., Wittel, A., Yang, N., Handran, S., Hughes, J. \& Costantin, J. (2006). Population patch clamp improves data consistency and success rates in the measurement of ionic currents. J Biomol Screen 11, 488-496

Hamer, A.M., Haxby, D.G., McFarland, B.H. \& Ketchum, K. (2002). Gabapentin use in a managed medicaid population. J Manag Care Pharm 8, 266-271

Hogg, D.S., Boden, P., Lawton, G. \& Kozlowski, R. (2006) Ion channel drug targetsunlocking the potential. Drug discov world, Vol.7, No.3, (August 2006), pp. 83-93, ISSN 1469-4344

Imming, P., Sinning, C. \& Meyer, A. (2006). Drugs, their targets and the nature and number of drug targets. Nat Rev Drug Discov 5, 821-834

Kang, J., Wang, L., Cai, F. \& Rampe, D. (2000). High affinity blockade of the HERG cardiac $\mathrm{K}(+)$ channel by the neuroleptic pimozide. Eur J Pharmacol 392, 137-140

Kornreich, B.G. (2007). The patch clamp technique: principles and technical considerations. J Vet Cardiol 9, 25-37

Kozlowski, R.Z. (1999) Chloride channels: Potential therapeutic targets, In: Chloride Channels, R.Z. Kozlowski, (Ed.), 177-186, ISIS Medical Media Ltd, Oxford, UK

Lepple-Wienhues, A., Ferlinz, K., Seeger, A. \& Schafer, A. (2003). Flip the tip: an automated, high quality, cost-effective patch clamp screen. Receptors Channels 9, 13-17

Li, S., Gosling, M., Poll, C.T., Westwick, J. \& Cox, B. (2005). Therapeutic scope of modulation of non-voltage-gated cation channels. Drug Discov Today 10, 129-137 
Mathes, C. (2006). QPatch: the past, present and future of automated patch clamp. Expert Opin Ther Targets 10, 319-327

Mathew, N.T., Rapoport, A., Saper, J., Magnus, L., Klapper, J., Ramadan, N., Stacey, B. \& Tepper, S. (2001). Efficacy of gabapentin in migraine prophylaxis. Headache 41, 119-128.

Morganroth, J. (2004). A definitive or thorough phase 1 QT ECG trial as a requirement for drug safety assessment. J Electrocardiol 37, 25-29

Neher, E. \& Sakmann, B. (1992). The patch clamp technique. Sci Am 266, 44-51

Neubert, H.J. (2004). Patch clamping moves to chips. Anal Chem 76, 327A-330A

Overington, J.P., Al-Lazikani, B. \& Hopkins, A.L. (2006). How many drug targets are there? Nat Rev Drug Discov 5, 993-996

Pearson, S. (2009) Investigating and focusing on ion channels as drug targets. Genetic Eng Biotech News Vol.29, No.11

Penner, R. (1995) A practical guide to patch clamping, in: Single-Channel Recording, B. Sakmann \& E. Neher, eds., (2nd ed). Plenum Press, NY, pp.3-30

Proks, P. \& Lippiat, J.D. (2006). Membrane ion channels and diabetes. Curr Pharm Des 12, 485-501

Rampe, D., Murawsky, M.K., Grau, J. \& Lewis, E.W. (1998). The antipsychotic agent sertindole is a high affinity antagonist of the human cardiac potassium channel HERG. J Pharmacol Exp Ther 286, 788-793

Salata, J.J., Jurkiewicz, N.K., Wallace, A.A., Stupienski, R.F., 3rd, Guinosso, P.J., Jr. \& Lynch, J.J., Jr. (1995). Cardiac electrophysiological actions of the histamine H1-receptor antagonists astemizole and terfenadine compared with chlorpheniramine and pyrilamine. Circ Res 76, 110-119

Sanguinetti, M.C. \& Jurkiewicz, N.K. (1990). Two components of cardiac delayed rectifier K+ current. Differential sensitivity to block by class III antiarrhythmic agents. J Gen Physiol 96, 195-215

Schroeder, K., Neagle, B., Trezise, D.J. \& Worley, J. (2003). Ionworks HT: a new highthroughput electrophysiology measurement platform. J Biomol Screen 8, 50-64

Spector, P.S., Curran, M.E., Keating, M.T. \& Sanguinetti, M.C. (1996). Class III antiarrhythmic drugs block HERG, a human cardiac delayed rectifier $\mathrm{K}^{+}$channel. Open-channel block by methanesulfonanilides. Circ Res 78, 499-503

Stett, A., Burkhardt, C., Weber, U., van Stiphout, P. \& Knott, T. (2003). CYTOCENTERING: a novel technique enabling automated cell-by-cell patch clamping with the CYTOPATCH chip. Receptors Channels 9, 59-66

Suessbrich, H., Schonherr, R., Heinemann, S.H., Attali, B., Lang, F. \& Busch, A.E. (1997a). The inhibitory effect of the antipsychotic drug haloperidol on HERG potassium channels expressed in Xenopus oocytes. Br J Pharmacol 120, 968-974

Suessbrich, H., Schonherr, R., Heinemann, S.H., Lang, F. \& Busch, A.E. (1997b). Specific block of cloned Herg channels by clofilium and its tertiary analog LY97241. FEBS Lett $414,435-438$

Tao, H., Santa Ana, D., Guia, A., Huang, M., Ligutti, J., Walker, G., Sithiphong, K., Chan, F., Guoliang, T., Zozulya, Z., et al. (2004). Automated tight seal electrophysiology for assessing the potential hERG liability of pharmaceutical compounds. Assay Drug Dev Technol 2, 497-506 
Thomas, D., Wendt-Nordahl, G., Rockl, K., Ficker, E., Brown, A.M. \& Kiehn, J. (2001). Highaffinity blockade of human ether-a-go-go-related gene human cardiac potassium channels by the novel antiarrhythmic drug BRL-32872. J Pharmacol Exp Ther 297, 753-761

Venter, J.C., Adams, M.D., Myers, E.W., Li, P.W., Mural, R.J., Sutton, G.G., Smith, H.O., Yandell, M., Evans, C.A., Holt, R.A., et al. (2001). The sequence of the human genome. Science 291, 1304-1351

Vitola, J., Vukanovic, J. \& Roden, D.M. (1998). Cisapride-induced torsades de pointes. J Cardiovasc Electrophysiol 9, 1109-1113

Vorperian, V.R., Zhou, Z., Mohammad, S., Hoon, T.J., Studenik, C. \& January, C.T. (1996). Torsade de pointes with an antihistamine metabolite: potassium channel blockade with desmethylastemizole. J Am Coll Cardiol 28, 1556-1561

Waldegger, S., Niemeyer, G., Morike, K., Wagner, C.A., Suessbrich, H., Busch, A.E., Lang, F. \& Eichelbaum, M. (1999). Effect of verapamil enantiomers and metabolites on cardiac $\mathrm{K}^{+}$channels expressed in Xenopus oocytes. Cell Physiol Biochem 9, 81-89

Walker, B.D., Singleton, C.B., Bursill, J.A., Wyse, K.R., Valenzuela, S.M., Qiu, M.R., Breit, S.N. \& Campbell, T.J. (1999). Inhibition of the human ether-a-go-go-related gene (HERG) potassium channel by cisapride: affinity for open and inactivated states. $\mathrm{Br}$ J Pharmacol 128, 444-450

Woosley, R.L. (1996). Cardiac actions of antihistamines. Annu Rev Pharmacol Toxicol 36, 233-252

Xu, J., Guia, A., Rothwarf, D., Huang, M., Sithiphong, K., Ouang, J., Tao, G., Wang, X. \& Wu, L. (2003). A benchmark study with sealchip planar patch-clamp technology. Assay Drug Dev Technol 1, 675-684

Yang, T., Snyders, D.J. \& Roden, D.M. (1995). Ibutilide, a methanesulfonanilide antiarrhythmic, is a potent blocker of the rapidly activating delayed rectifier $\mathrm{K}^{+}$ current (IKr) in AT-1 cells. Concentration-, time-, voltage-, and use-dependent effects. Circulation 91, 1799-1806

Zhang, S., Zhou, Z., Gong, Q., Makielski, J.C. \& January, C.T. (1999). Mechanism of block and identification of the verapamil binding domain to HERG potassium channels. Circ Res 84, 989-998

Zheng, J. (2006). Patch fluorometry: shedding new light on ion channels. Physiology (Bethesda) 21, 6-12

Zhou, Z., Vorperian, V.R., Gong, Q., Zhang, S. \& January, C.T. (1999). Block of HERG potassium channels by the antihistamine astemizole and its metabolites desmethylastemizole and norastemizole. J Cardiovasc Electrophysiol 10, 836-843

Zolotoy, A.B., Plouvier, B.P., Beatch, G.B., Hayes, E.S., Wall, R.A. \& Walker, M.J. (2003). Physicochemical determinants for drug induced blockade of HERG potassium channels: effect of charge and charge shielding. Curr Med Chem Cardiovasc Hematol Agents 1, 225-241 


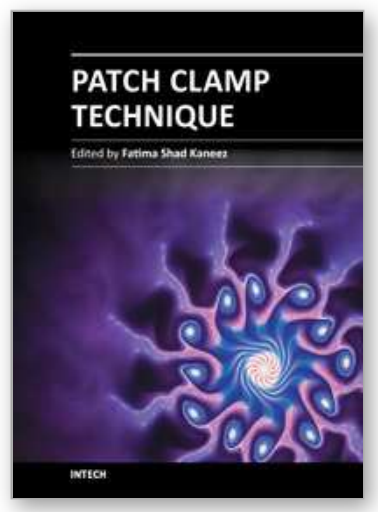

\author{
Patch Clamp Technique \\ Edited by Prof. Fatima Shad Kaneez
}

ISBN 978-953-51-0406-3

Hard cover, 356 pages

Publisher InTech

Published online 23, March, 2012

Published in print edition March, 2012

This book is a stimulating and interesting addition to the collected works on Patch clamp technique. Patch Clamping is an electrophysiological technique, which measures the electric current generated by a living cell, due to the movement of ions through the protein channels present in the cell membrane. The technique was developed by two German scientists, Erwin Neher and Bert Sakmann, who received the Nobel Prize in 1991 in Physiology for this innovative work. Patch clamp technique is used for measuring drug effect against a series of diseases and to find out the mechanism of diseases in animals and plants. It is also most useful in finding out the structure function activities of compounds and drugs, and most leading pharmaceutical companies used this technique for their drugs before bringing them for clinical trial. This book deals with the understanding of endogenous mechanisms of cells and their receptors as well as advantages of using this technique. It covers the basic principles and preparation types and also deals with the latest developments in the traditional patch clamp technique. Some chapters in this book take the technique to a next level of modulation and novel approach. This book will be of good value for students of physiology, neuroscience, cell biology and biophysics.

\title{
How to reference
}

In order to correctly reference this scholarly work, feel free to copy and paste the following:

Yan Long and Zhiyuan Li (2012). Drug Screening and Drug Safety Evaluation by Patch Clamp Technique, Patch Clamp Technique, Prof. Fatima Shad Kaneez (Ed.), ISBN: 978-953-51-0406-3, InTech, Available from: http://www.intechopen.com/books/patch-clamp-technique/drug-screening-and-drug-safety-evaluation-bypatch-clamp-technique

\section{INTECH}

open science | open minds

\section{InTech Europe}

University Campus STeP Ri

Slavka Krautzeka 83/A

51000 Rijeka, Croatia

Phone: +385 (51) 770447

Fax: +385 (51) 686166

www.intechopen.com

\section{InTech China}

Unit 405, Office Block, Hotel Equatorial Shanghai

No.65, Yan An Road (West), Shanghai, 200040, China

中国上海市延安西路 65 号上海国际贵都大饭店办公楼 405 单元

Phone: +86-21-62489820

Fax: $+86-21-62489821$ 
(C) 2012 The Author(s). Licensee IntechOpen. This is an open access article distributed under the terms of the Creative Commons Attribution 3.0 License, which permits unrestricted use, distribution, and reproduction in any medium, provided the original work is properly cited. 